\title{
Sodium Hypochlorite
}

National Cancer Institute

\section{Source}

National Cancer Institute. Sodium Hypochlorite. NCI Thesaurus. Code C80658.

A chlorine compound often used as a disinfectant or a bleaching agent. Sodium

hypochlorite in $0.5 \% \mathrm{w} / \mathrm{v}$ solution is called Dakin's solution, and is used as an antiseptic to clean infected topical wounds. 